\title{
CEO Effectiveness For Leading Pre-Event Natural Disaster Preparedness Planning To Meet The Needs Of Employees And Their Families
}

James L. Morrison, Ph.D., University of Delaware, USA G. Titi Oladujoye, Ph.D., Albany State University, USA

\begin{abstract}
The findings of this study suggest that there appears to be some disparity among managers in their perceptions to the degree of the effectiveness of their CEO in leading organizational natural disaster preparedness. In this regard, there appears to be agreement among managers that their leadership has been effective in putting into place practices to assess current risks and to have a back-up infrastructure in place to resume operations quickly once a natural disaster hits. However, they generally disagree that their organizations are prepared to support the individual needs of employees and their families during a natural disaster.
\end{abstract}

Keywords: Natural Disaster Preparedness; Disaster Planning; Disaster Readiness

\section{INTRODUCTION}

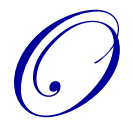

rganizational crises resulting from direct impacts of natural disasters such as tornadoes, earthquakes, and flooding often result in abrupt or disruptive changes not only to operational practices but also to the lives of employees and their families. In this regard, such disasters typically pose economic, social and psychological challenges to employees at work as well as families outside the typical boundaries of the organizational infrastructure. As natural disasters have become more prevalent in recent years (as witnessed by the recent tsunami in Japan and earthquakes in China, Italy, and Pakistan), pre-event planning to have procedures and practices in place is critical for any organization.

The question that begs attention is how well are American companies actually prepared to provide immediate assistance to employees and their families for coping with a natural disaster, if one suddenly occurs. The focus here is to compare the views of managers as to the effectiveness of procedures and practices put in place by their CEO through pre-event planning for readying workers to anticipate tasks that need (1) to be carried out in order to address the personal needs of workers and (2) to assure a quick recovery of operational functions. Natural disasters test the ability of leaders of organizations to effectively protect their employees and their families, as well as their infrastructure, to reduce both human and property loss. The seemingly randomness of impacts of incidents demand effective and cost-efficient operational strategies, thus making the topic of organizational effectiveness an intriguing target for scholarly research. For this research, a natural disaster is defined as a sudden catastrophic event that is the result of atmospheric and other geological imbalances that threatens the viability of an organization and is characterized by creating chaos, disruption of operations, confusion, and even the death of employees.

\section{Stages to Natural Disaster Preparedness}

Natural disaster preparedness is typically delineated in terms of four continuous stages: mitigation, readiness, response, and recovery ([Waugh, 2000], [Godschalk, 1991] and [Waugh and Hy, 1990]). The two preevent planning stages, the focus of this research, are: (1) mitigation which focuses upon the planning ahead by 
putting an operational framework in place to reduce disaster impacts; and (2) readiness which targets before-event planning tasks that are designed to be implemented when a natural disaster actually occurs. For this study, the target is gathering data from those in mid-management positions to analyze CEO effectiveness in leading others in mitigating the probable consequences of a natural disaster should one occur, be it a tornado, earthquake, hurricane, flood, or any other sudden natural event. Pre-event natural disaster preparedness involves putting into place policies, practices, and procedures for readying an organization for a sudden organizational emergency.

\section{LITERATURE REVIEW}

Although natural disasters generally have a low probability of occurring, they nevertheless pose a major threat to the survival of an organization (Jackson \& Dutton, 1988; Shrivastava, et al., 1988). However, Bankoff (2004) found that those in leadership positions typically do not understand the magnitude of their impact on an organization that is suddenly without communication capabilities, utilities, key decision-makers and information required to function rationally. Therefore, Bankoff suggests that those in leadership positions may not only be vulnerable to short-term interruptions, but also to long-term impacts, such as financial loss and even displacement, thus affecting employees and their families directly. Similarly, in a study of the 118 businesses, Thomas Drabak (2001) at the University of Denver found that over half of the 118 businesses surveyed were ill prepared for the type of disaster they eventually confronted. Based upon employee interviews conducted after the natural disaster, employees indicated that the supervisory personnel gave inadequate guidance, thus revealing a failure in leadership. $\mathrm{He}$ found that confusion at the time of the natural disaster raised tension among employees, resulting in conflicts between work and family priorities.

In addition, Wooten (2008) and James (2008) found in their research that most executives are generally aware of the negative consequences associated with an organizational crisis, but they typically have a personal laissez-faire attitude towards actively participating in the planning process. To these researchers, employees perceive the CEO as being generally removed from pre-event planning. In this regard, Kunreuther and Useem (2010) argue that there is a continuous need for organizations to have formal policies and procedures in place to minimize the effects of a natural tragedy upon operational functions, including infrastructure, as well as the family of the employee.

Hutchins, Annulis, and Gaudet (2008) point out that natural disaster crisis pre-event planning generally has been an overlooked researched area in the organizational leadership literature. To them, organizational infrastructure, the security of data and the backing-up of information systems have been the target of study in recent years. However, they also indicate that areas of leadership assertiveness not generally studied in the past include analyzing the pre-event planning processes for putting into place policies and procedures (1) to rescue employees from immediate harm; (2) to address the immediate needs of family members affected; and (3) to establish an organizational culture that is personally aware, involved and committed. However, in their study of crisis impacts seven months after Hurricane Katrina, results indicated that organizations generally did modestly increase efforts in disaster preplanning.

Ironically, some two decades ago, Carney and Jorden (1993) stated that managers generally believe that senior leadership should become more proactive in pre-event planning to avoid the unnecessary destruction of both facilities and human life resulting from an unpredictable event. During the same time period, Tiller (1994) concluded that approximately 40 percent of the Fortune 1000 industrial companies did not have an operational crisis plan in place. Four years later, Burnett also concluded that "50 to 70 percent of the largest profit-making organizations in the United States haven't made any disaster plans" (Burnett, 1998, p. 475). Finally, according to a PR Week/Burson-Marsteller CEO reputation survey, 21 percent of the 194 CEOs who responded indicated they had no natural disaster crisis plan whatsoever. (Bloom, 2001). More recently, Schoenberg (2010), after a meta-analysis of research on crisis preparation and planning, reported that there is a scarcity of formal research performed on preevent natural disaster planning while post-event analysis has been a primary target.

Similarly, Pauchant \& Mitroff (1992) report that most data collected on crisis impacts has been obtained through interviews and surveys after-the-event has occurred. Based on their research, they also state that those in senior leadership positions appear to rely much on public sector support (e.g., Federal, and State emergency 
services) and community non-profit agencies to assist in providing aid to affected employees and their families. While leaders do realize that a crisis has the potential to disrupt operations of an entire organization (Coombs, 1999), they tend to downplay their involvement in pre-event planning. Accordingly, a 2003 study published in the Harvard Business Review indicated that only between 5 and 25 percent of Fortune 500 companies were prepared to cope with a crisis, leaving approximately 75 percent not prepared (Mitroff \& Alpaslan, 2004). Finally, based on another study conducted after the impact of Hurricane Katrina, Runyan (2006) found that there was a lack of planning especially by small businesses; a vulnerability to cash flow; serious infrastructure problems impeding recovery, and little attention to employee and family survival issues.

\section{STATEMENT OF THE PROBLEM}

As reported in the search of the literature above, there has not been much published on leadership effectiveness in pre-event planning to support individual employee and family needs. Therefore, the purpose of this study was to determine the degree of leadership effectiveness from the viewpoint of organizational managers for addressing issues related to the human side of a natural disaster. What is unique here is the use of a research design that results in a multi-dimensional perspective by comparing managers with varying degrees of education and work experience. In order to do a more in-depth study of leadership effectiveness, the null hypothesis tested is that the perceptions of those in mid-management positions in the manufacturing sector of the effectiveness of their CEO in leading in organizational preparedness for synergizing pre-event planning practices to address needs of employees and their families will not vary by region of the country, size of organization, length of employment, and education level. The pre-event data collecting strategy used in this study enabled the gathering of comparative data as related to leadership priorities for addressing infrastructure issues versus direct human needs.

The CEO generally plays a strategic role in getting anything done in an organization. With the results of recent research (some 5 years in the past) indicating that CEO's intend to enhance natural disaster preparedness, has the CEO actually become more engaged by assuming personal leadership to ensure the sustainability of their organizations while at the same time protecting the interests of their employees and families? To answer this question, this research adopts an intriguing design by targeting those who are perhaps most directly affected by the actions of their CEO, the manager. Their perceptions should provide another dimension as to how prepared we actually are by either verifying previous CEO intent or disproving considerable enhancement in this regard. In addition, the focus of this research is on the manufacturing sector since a significant disruption in the production of goods is likely to result in devastating consequences to the livelihood of a large number of Americans. (National Association of Manufacturers, 2009).

\section{METHODOLOGY}

The primary source of data for the study were those in mid-management positions in manufacturing organizations in the private sector within the confines of the boarders to the United States. An online survey instrument used for gathering data was designed through the University of Delaware Qualtrics Access protocol.

\section{Instrument Design}

The data gathering instrument focused on those practices identified as part of a pre-event disaster planning process; specifically, to mitigation and organizational readiness. The original survey form was completed by nine managers from the Delaware-Pennsylvania-New Jersey Regions. After getting feedback from the consulting group, several items were deleted from the original instrument and several other items were revised. As the result of this process, the instrument has content validity. Thus, the survey form consisted of six practices related to the attention the CEO to natural disaster preparedness. A 5-point rating scale permitting strongly agree to strongly disagree responses was adopted for recording perspectives of those in the sample

\section{Research Sample}

Using a national data base of other 50,000 managers (American Business Data Base, 2012), a random sample of 1000 managers was selected. The instrument was delivered online during a two-week span in January 
2012. Complete sets of data were collected from 120, representing 12 percent return. Those in the sample were sent 2 reminders to complete the survey online.

\section{Statistical Measures}

Using a 5-point nominal rating scale to collect data, the Kruskal-Wallis nonparametric independent samples test was performed on the four dependent variables identified for study: length of employment, educational level of manager, size of organization and region of the country. Due to the fact that there were few responses in the strongly agree and strongly disagree categories, responses to the 5-point scale were regrouped to +1 to signify agree or strongly agree; 0 , for no opinion; and -1 , for disagree or strongly disagree. By grouping responses into three categories, the sufficient number of responses was generated for statistical measures to be calculated. In addition, a Cronbach Reliability Test was conducted in which a coefficient of .85 was calculated, which is well- above the .70 generally required for accepting survey reliability.

\section{FINDINGS}

Of the 120 managers in the sample, 101 were male and 19, female. In terms of the region of the country, the sample was well distributed throughout the country with 54 managers from coastal states (those bordering either the Atlantic or Pacific Ocean or the Gulf of Mexico); 24, from North Central States (those in northern $1 / 2$ of country); and 34, from South Central States (those in southern $1 / 2$ of country). In terms of educational level, 47 had a bachelor's degree, and 57, an advanced degree, with both degrees representing 85 percent of the sample. However, about 15 percent (or 19 individuals) of the sample possessed either a secondary school diploma or had some college education. In terms of length of employment, 72 managers had 11 or more years of employment at their company and 48 had 10 years or less. Finally, only 17 in the sample were employed in companies having over 1000 employees whereas 103 were situated in either mid to small companies.

Based upon the overall mean scores of perceptions of managers as to the effectiveness of their CEO in leading natural disaster preparedness planning, there is a general disagreement that their senior leadership has been effective in this regard. Using a rating scale where +1 indicated agreement, -1 , disagreement; and 0 , no opinion (Table 1), the overall negative means calculated indicated that the managers generally disagreed that their leadership had raised risk awareness level of employees $(\mathrm{m}=-.20)$, had sufficient back-up systems in place to communicate with employees and their families $(\mathrm{m}=-.33)$, had practices in place to get medical assistance and other aid directly to employees impacted $(\mathrm{m}=-.05)$, and had addressed possible psychological, social and financial issues of worker and their families $(\mathrm{m}=-.48)$. However, the managers generally agreed that their CEO had conducted a preevent natural disaster risk assessment $(\mathrm{m}=+.26)$ and had an infrastructure in place to resume operations quickly $(\mathrm{m}=+.30)$.

Table 1

Overall Frequency Distribution of Perceptions of Managers on CEO Effectiveness for Demonstrating Leadership for Implementing Pre-Event Planning Practices to Address Both Personal/Family and Organizational Needs (N=120)

\begin{tabular}{|c|c|c|c|c|c|}
\hline Current Practices in Place to: & -1 & $\mathbf{0}$ & +1 & Mean & Variance \\
\hline Raise the Nat. Disaster Risk-Level Awareness & 57 & 30 & 33 & -.20 & .716 \\
\hline Conduct Nat. Disaster Risk Assessment of Facilities & 40 & 9 & 71 & +.26 & .865 \\
\hline Have Back-Up Systems to Communicate w/Employees & 73 & 14 & 33 & -.33 & .818 \\
\hline Have infrastructure in Place to Resume Operations & 37 & 10 & 73 & +.30 & .834 \\
\hline $\begin{array}{l}\text { Coordinate with Public Agencies to Get Medical } \\
\text { Assistance to Affected Employees }\end{array}$ & 55 & 16 & 49 & -.05 & .871 \\
\hline $\begin{array}{l}\text { Attend to Psychological, Social, and Financial Issues } \\
\text { Of Employees and Their Families }\end{array}$ & 82 & 13 & 25 & -.48 & .672 \\
\hline
\end{tabular}

Note: Rating Scale: -1 = ineffective; $0=$ no opinion; $+1=$ effective

In analyzing responses of managers by region of the country, there were generally no significant differences in perceptions of managers. Using the Kruskal-Wallis Test for independent samples for comparing responses of 50 managers situated in coastal states, 24 in north-central states, and 46 in south-central states (Table 2), responses were similar in either the degree of agreement or disagreement for each of the six pre-event practices 
on the survey. In this regard, the CEO is perceived as being ineffective (negative mean ratings) when attending to human needs related to (1) communicating with employees and their families, (2) getting assistance directly to those in need, and (3) attending to psychological and other personal issues of employees no matter where the company is located (Table 2).

Table 2

Comparison of Perceptions of Managers on CEO Effectiveness for Implementing Actual Pre-Disaster Planning Practices to Address Both Personal and Organizational Needs by Region of Country $(N=120)$

\begin{tabular}{|c|c|c|c|c|c|c|c|}
\hline $\begin{array}{c}\text { Practices Currently } \\
\text { Applicable to: }\end{array}$ & Ob. ${ }^{-1^{d}}{ }^{c}{ }^{c}$ & $\begin{array}{c}0 \\
\text { Ob. Ex. }\end{array}$ & $\begin{array}{c}+1 \\
\text { Ob. Ex. }\end{array}$ & Mean & T-Stat ${ }^{\text {b }}$ & df & Signf. \\
\hline $\begin{array}{l}\text { Raise Risk Level Awareness } \\
1^{\mathrm{a}} \\
2 \\
3\end{array}$ & $\begin{aligned} 31 & (23.8) \\
8 & (11.4) \\
18 & (21.9)\end{aligned}$ & $\begin{aligned} 10 & (12.5) \\
8 & (6.0) \\
12 & (11.5)\end{aligned}$ & $\begin{aligned} 9 & (13.8) \\
8 & (6.6) \\
16 & (12.7)\end{aligned}$ & $\begin{array}{l}-.44 \\
-.00 \\
-.04\end{array}$ & 7.218 & 2 & .027 \\
\hline $\begin{array}{c}\text { Conduct Risk Assessment } \\
1 \\
2 \\
3\end{array}$ & $\begin{array}{rr}21 & (16.7) \\
9 & (8.0) \\
10 & (15.3) \\
\end{array}$ & $\begin{array}{ll}4 & (3.8) \\
1 & (1.8) \\
4 & (3.5)\end{array}$ & $\begin{array}{ll}25 & (29.6) \\
14 & (14.2) \\
32 & (27.2) \\
\end{array}$ & $\begin{array}{l}.08 \\
.21 \\
.48\end{array}$ & 4.348 & 2 & .114 \\
\hline $\begin{array}{l}\text { Have Back-up Systems to } \\
\text { Communicate w/employees } \\
1 \\
2 \\
3\end{array}$ & $\begin{array}{ll}32 & (30.4) \\
16 & (14.6) \\
25 & (28.0) \\
\end{array}$ & $\begin{array}{ll}4 & (5.8) \\
4 & (2.8) \\
6 & (5.4)\end{array}$ & $\begin{aligned} & 14(13.8) \\
& 4(6.6) \\
& 15(12.7) \\
&\end{aligned}$ & $\begin{array}{l}-.36 \\
-.50 \\
-.22\end{array}$ & 1.585 & 2 & .453 \\
\hline $\begin{array}{l}\text { Have Infrastructure in Place to } \\
\text { Resume Operations } \\
1 \\
2 \\
3 \\
\end{array}$ & $\begin{aligned} & 19(15.4) \\
& 6(7.4) \\
& 12(14.2) \\
&\end{aligned}$ & $\begin{array}{ll}2 & (4.2) \\
6 & (2.0) \\
2 & (3.8)\end{array}$ & $\begin{array}{ll}29 & (30.4) \\
12 & (14.6) \\
32 & (28.0) \\
\end{array}$ & $\begin{array}{l}.20 \\
.25 \\
.43 \\
\end{array}$ & 1.861 & 2 & .395 \\
\hline $\begin{array}{l}\text { Coordinate with Public Agencies } \\
\text { to Assist Affected Employees } \\
1 \\
2 \\
3\end{array}$ & $\begin{array}{ll}26 & (22.9) \\
12 & (11.0) \\
17 & (21.1)\end{array}$ & $\begin{array}{ll}5 & (6.7) \\
5 & (3.2) \\
6 & (6.1)\end{array}$ & $\begin{aligned} & 19(20.4) \\
& 7(9.8) \\
& 23(18.8) \\
&\end{aligned}$ & $\begin{array}{l}-.14 \\
-.21 \\
+.13\end{array}$ & 2.855 & 2 & .240 \\
\hline $\begin{array}{l}\text { Attend to Psych., Social \& } \\
\text { Financial Issues of } \\
\text { Employees/Families } \\
1 \\
2 \\
3 \\
\end{array}$ & $\begin{array}{ll}36 & (34.2) \\
17 & (16.4) \\
29 & (31.4) \\
\end{array}$ & $\begin{array}{ll}5 & (5.4) \\
2 & (2.6) \\
6 & (5.0) \\
\end{array}$ & $\begin{array}{rr}9 & (10.4) \\
5 & (5.0) \\
11 & (9.6) \\
\end{array}$ & $\begin{array}{l}-.54 \\
-.50 \\
-.39 \\
\end{array}$ & .906 & 2 & .636 \\
\hline
\end{tabular}

Note: $\quad$ a - $\quad 1=50$ Coastal States; $2=24$ Northern States; $3=46$ Southern States

b - Kruskal-Wallis Independent Samples Statistical Measure

c - ob = observed; ex = expected

d - -1 = ineffective; $0=$ no opinion; $+1=$ effective

*significance at .05 level

In terms of size of the company, there were systematic significant differences in their perceptions of their CEO putting practices in place to cope with a sudden natural disaster. The findings indicate that those managers in large operations demonstrated considerably a greater degree of agreement that their CEO was effective in pre-event planning to cope with a natural disaster than those in small to mid-size organizations. (Table 3) Specifically, managers in small organizations perceived themselves less prepared than their counterparts in mid- to large-size companies in the manufacturing sector. In terms for the CEO having backup systems in place to communicate with employees and their families, to attend to medical needs of workers, etc., and to address psychological, social, and financial scars resulting from a natural disaster, those managers in small companies were significantly negative $(\mathrm{m}=-$ $.51, \mathrm{~m}=-.53 . \mathrm{m}=-.72$ ) as compared to their counterparts in large organizations who were much more positive about the effectiveness of their CEO $(\mathrm{m}=+.88, \mathrm{~m}=+.71, \mathrm{~m}=+.65)$. In regards to preparing for infrastructure and risk assessment issues in particular, those managers in mid-size companies $(\mathrm{m}=+.44, \mathrm{~m}=+.36)$ were more aligned to the positive perceptions of those in large companies generally $(\mathrm{m}=+.76, \mathrm{~m}+.100)$ (Table 3$)$. 
Table 3

Comparison of Perceptions of Managers on CEO Effectiveness for Implementing Actual Pre-Disaster Planning Practices to Address Both Personal and Organizational Needs by Size of Company $(\mathrm{N}=120)$

\begin{tabular}{|c|c|c|c|c|c|c|c|}
\hline $\begin{array}{c}\text { Practices Currently } \\
\text { Applicable to: }\end{array}$ & Ob. $^{-1^{\mathrm{d}}}$ Ex. $^{\mathrm{c}}$ & $\begin{array}{c}\mathbf{0} \\
\text { Ob. Ex. }\end{array}$ & $\begin{array}{c}+1 \\
\text { Ob. Ex. }\end{array}$ & Mean & T-Stat ${ }^{b}$ & df & Signf. \\
\hline $\begin{array}{l}\text { Raise Risk Level Awareness } \\
\qquad 1^{\mathrm{a}} \\
2 \\
3\end{array}$ & $\begin{array}{cc}34 & (25.2) \\
20 & (23.8) \\
3 & (8.9)\end{array}$ & $\begin{array}{cc}14 & (13.3) \\
4 & (12.5) \\
12 & (4.3)\end{array}$ & $\begin{aligned} 5 & (14.6) \\
26 & (13.8) \\
2 & (4.7)\end{aligned}$ & $\begin{array}{l}-.55 \\
+.12 \\
-.06\end{array}$ & 15.403 & 2 & $.000 *$ \\
\hline $\begin{array}{c}\text { Conduct Risk Assessment } \\
1 \\
2 \\
3 \\
\end{array}$ & $\begin{aligned} & 27(17.7) \\
& 12(16.7) \\
& 1(5.7) \\
&\end{aligned}$ & $\begin{array}{ll}3 & (4.0) \\
4 & (3.8) \\
2 & (1.3)\end{array}$ & $\begin{array}{ll}23 & (31.4) \\
34 & (29.6) \\
14 & (10.1)\end{array}$ & $\begin{array}{l}-.08 \\
+.44 \\
+.76\end{array}$ & 13.156 & 2 & $.001 *$ \\
\hline $\begin{array}{l}\text { Have Back-up Systems to } \\
\text { Communicate w/employees } \\
1 \\
2 \\
3\end{array}$ & $\begin{array}{cc}37 & (32.2) \\
35 & (30.4) \\
1 & (10.3)\end{array}$ & $\begin{array}{ll}6 & (6.2) \\
8 & (5.8) \\
0 & (2.0)\end{array}$ & $\begin{array}{cc}10 & (14.6) \\
7 & (13.8) \\
16 & (4.7)\end{array}$ & $\begin{array}{l}-.51 \\
-.56 \\
+.88\end{array}$ & 34.080 & 2 & $.000 *$ \\
\hline $\begin{array}{l}\text { Have Infrastructure in Place to } \\
\text { Resume Operations } \\
1 \\
2 \\
3 \\
\end{array}$ & $\begin{aligned} 24 & (16.3) \\
13 & (15.4) \\
0 & (5.2)\end{aligned}$ & $\begin{array}{ll}4 & (4.4) \\
6 & (4.2) \\
0 & (1.0)\end{array}$ & $\begin{array}{ll}25 & (32.2) \\
31 & (30.4) \\
17 & (10.3) \\
\end{array}$ & $\begin{array}{r}+.02 \\
+.36 \\
+1.00\end{array}$ & 15.392 & 2 & $.000 *$ \\
\hline $\begin{array}{l}\text { Coordinate with Public Agencies } \\
\text { to Assist Affected Employees } \\
1 \\
2 \\
3\end{array}$ & $\begin{aligned} 40 & (24.3) \\
14 & (22.9) \\
1 & (7.8)\end{aligned}$ & $\begin{array}{cc}1 & (7.1) \\
12 & (6.7) \\
3 & (2.3)\end{array}$ & $\begin{array}{cl}12 & (21.6) \\
24 & (20.4) \\
13 & (6.9) \\
\end{array}$ & $\begin{array}{l}-.53 \\
+.20 \\
+.71\end{array}$ & 29.107 & 2 & $.000 *$ \\
\hline $\begin{array}{l}\text { Attend to Psych., Social \& } \\
\text { Financial Issues of } \\
\text { Employees/Families } \\
1 \\
2 \\
3\end{array}$ & $\begin{array}{cc}42 & (36.2) \\
38 & (34.2) \\
2 & (11.6)\end{array}$ & $\begin{array}{ll}7 & (5.7) \\
4 & (5.4) \\
2 & (1.8)\end{array}$ & $\begin{array}{cc}4 & (11.0) \\
8 & (10.4) \\
13 & (3.5)\end{array}$ & $\begin{array}{l}-.72 \\
-.60 \\
+.65\end{array}$ & 34.528 & 2 & $.000 *$ \\
\hline
\end{tabular}

Note: $\quad \mathrm{a}-1=53$ (0-250 employees); $2=50$ (251-1000 employees); $3=17$ (1001+ employees)

b - Kruskal-Wallis Independent Samples Statistical Measure

c - $\quad$ ob $=$ observed; ex $=$ expected

$\mathrm{d}-\quad-1=$ ineffective; $0=$ no opinion; $+1=$ effective

*significance at .05 level

Based upon the educational level of the manager, there were also significant differences in the degree of disagreement among their perceptions as to the effectiveness of their CEO in putting into place practices to address personal needs of employees and their families (Table 4). Generally, those managers holding a Master's degree or an advanced post-Master's degree were in significantly greater disagreement that their CEO has been demonstrating effective leadership than managers with lesser educational accomplishment. In regards to having back-up systems in place to communicate with employees and families, those managers with a Master's degree $(\mathrm{m}=-.84)$ and those with a Post-Master's work $(\mathrm{m}=-.88)$ were in significantly more disagreement that their CEO has been effective than those with a baccalaureate degree $(\mathrm{m}=-.04)$ and those with a diploma or some college $(\mathrm{m}=+.42)$. Similarly, those with a Master's or Post-Master's work held very negative perceptions as to their CEO effectiveness $(\mathrm{m}=-1.00 . \mathrm{m}=-1.00)$ that their counterparts $(\mathrm{m}=+.05, \mathrm{~m}=-.09)($ Table 4$)$. 
Table 4

Comparison of Perceptions of Managers on CEO Effectiveness for Implementing Actual Pre-Disaster Planning Practices to Address Both Personal and Organizational Needs by Educational Level $(\mathrm{N}=120)$

\begin{tabular}{|c|c|c|c|c|c|c|c|}
\hline $\begin{array}{c}\text { Practices Currently } \\
\text { Applicable to: }\end{array}$ & Ob. ${ }^{-1^{\mathrm{d}}}{ }^{\mathrm{Ex}}{ }^{\mathrm{c}}$ & $\begin{array}{c}0 \\
\text { Ob. Ex. }\end{array}$ & $\begin{array}{c}+1 \\
\text { Ob. Ex. }\end{array}$ & Mean & T-Stat ${ }^{b}$ & df & Signf. \\
\hline $\begin{array}{c}\text { Raise Risk Level Awareness } \\
1^{\mathrm{a}} \\
2 \\
3 \\
4\end{array}$ & $\begin{array}{cc}4 & (9.0) \\
21 & (22.3) \\
19 & (17.6) \\
13 & (8.1)\end{array}$ & $\begin{array}{cl}10 & (4.8) \\
16 & (11.8) \\
2 & (9.3) \\
2 & (4.3)\end{array}$ & $\begin{array}{cl}5 & (5.2) \\
10 & (12.9) \\
16 & (10.2) \\
2 & (4.7)\end{array}$ & $\begin{array}{l}+.05 \\
-.23 \\
-.08 \\
-.65\end{array}$ & 7.739 & 3 & .052 \\
\hline $\begin{array}{c}\text { Conduct Risk Assessment } \\
1 \\
2 \\
3 \\
4 \\
\end{array}$ & $\begin{aligned} 4 & (6.3) \\
15 & (15.7) \\
18 & (12.3) \\
3 & (5.7)\end{aligned}$ & $\begin{array}{ll}1 & (1.4) \\
4 & (3.5) \\
2 & (2.8) \\
2 & (1.3) \\
\end{array}$ & $\begin{array}{ll}14 & (11.3) \\
28 & (27.8) \\
17 & (21.9) \\
12 & (10.1)\end{array}$ & $\begin{array}{l}+.53 \\
+.28 \\
-.03 \\
+.53 \\
\end{array}$ & 6.253 & 3 & .100 \\
\hline $\begin{array}{l}\text { Have Back-up Systems to } \\
\text { Communicate w/Employees } \\
\qquad \begin{array}{c}1 \\
2 \\
3 \\
4\end{array}\end{array}$ & $\begin{array}{rr}3 & (32.2) \\
23 & (30.4) \\
32 & (10.3) \\
15 & (10.3)\end{array}$ & $\begin{array}{ll}5 & (6.2) \\
3 & (5.8) \\
4 & (2.0) \\
2 & (2.0)\end{array}$ & $\begin{aligned} 11 & (14.6) \\
21 & (12.9) \\
1 & (10.2) \\
0 & (4.7)\end{aligned}$ & $\begin{array}{l}+.42 \\
-.04 \\
-.84 \\
-.88\end{array}$ & 37.330 & 3 & $.000 *$ \\
\hline $\begin{array}{l}\text { Have Infrastructure in Place to } \\
\text { Resume Operations } \\
1 \\
2 \\
3 \\
4\end{array}$ & $\begin{aligned} 2 & (5.8) \\
21 & (14.5) \\
2 & (11.4) \\
12 & (5.2)\end{aligned}$ & $\begin{array}{ll}0 & (3.9) \\
1 & (4.2) \\
6 & (3.1) \\
3 & (1.4)\end{array}$ & $\begin{array}{cc}17 & (10.5) \\
25 & (28.6) \\
29 & (22.5) \\
2 & (10.3)\end{array}$ & $\begin{array}{l}+.79 \\
+.09 \\
+.73 \\
-.59\end{array}$ & 31.855 & 3 & $.000 *$ \\
\hline $\begin{array}{l}\text { Coordinate with Public Agencies to } \\
\text { Assist Affected Employees } \\
1 \\
2 \\
3 \\
4 \\
\end{array}$ & $\begin{array}{cl}2 & (8.7) \\
20 & (21.5) \\
16 & (17.0) \\
17 & (7.8) \\
\end{array}$ & $\begin{array}{ll}3 & (2.5) \\
5 & (6.3) \\
8 & (4.9) \\
0 & (2.3) \\
\end{array}$ & $\begin{array}{rr}14 & (7.7) \\
22 & (19.2) \\
13 & (15.1) \\
0 & (6.9) \\
\end{array}$ & $\begin{array}{c}+.63 \\
+.04 \\
-.08 \\
+1.00 \\
\end{array}$ & 28.446 & 3 & $.000 *$ \\
\hline $\begin{array}{l}\text { Attend to Psych., Social \& } \\
\text { Financial Issues of } \\
\text { Employees/Families } \\
1 \\
2 \\
3 \\
4\end{array}$ & $\begin{array}{cc}4 & (36.2) \\
24 & (34.2) \\
37 & (11.6) \\
17 & (11.6)\end{array}$ & $\begin{array}{cc}10 & (2.0) \\
3 & (5.1) \\
0 & (4.0) \\
0 & (1.8)\end{array}$ & $\begin{aligned} 5 & (11.0) \\
20 & (10.4) \\
0 & (7.7) \\
0 & (3.5)\end{aligned}$ & $\begin{array}{l}+.05 \\
-.09 \\
-1.00 \\
-1.00\end{array}$ & 45.758 & 3 & $.000 *$ \\
\hline
\end{tabular}

Note: a - $1=19$ (Some College); $2=47$ (4-yr. Baccalaureate); $3=37$ (Master's); $4=17$ (post Master's)

b - Kruskal-Wallis Independent Samples Statistical Measure

c - ob = observed; ex = expected

$\mathrm{d}-\quad-1=$ ineffective; $0=$ no opinion; $+1=$ effective

*significance at .05 level

In terms of length of employment, there was a significant difference among the perceptions of managers as to the implementation of practices to enhance disaster preparedness for each of the six items on the online survey questionnaire. Those managers being relatively new to an organization (between 0 to 5 years) had significantly more positive perceptions of their CEO's effectiveness in having back-up systems in place to communicate with employees and families, in coordinating medical assistance directly to affected employees, and attending to psychological, social and financial issues of employees and their families $(\mathrm{m}=+.42, \mathrm{~m}=+.79, \mathrm{~m}=+.11)$ (Table 5). 
Table 5

Comparison of Perceptions of Managers on CEO Effectiveness for Implementing Actual Pre-Disaster Planning Practices to Address Both Personal and Organizational Needs by Length of Employment $(\mathrm{N}=120)$

\begin{tabular}{|c|c|c|c|c|c|c|c|}
\hline $\begin{array}{c}\text { Practices Currently } \\
\text { Applicable to: }\end{array}$ & Ob. ${ }^{-1^{\mathrm{d}}}$ Ex. $^{\mathrm{c}}$ & $\begin{array}{c}\mathbf{0} \\
\text { Ob. Ex. }\end{array}$ & $\begin{array}{l}+1 \\
\text { Ob. Ex. }\end{array}$ & Mean & T-Stat ${ }^{\mathbf{b}}$ & df & Signf. \\
\hline $\begin{array}{c}\text { Raise Risk Level Awareness } \\
1^{\text {a }} \\
2 \\
3 \\
4 \\
\end{array}$ & $\begin{array}{cl}2 & (9.0) \\
22 & (13.8) \\
9 & (16.2) \\
24 & (18.1) \\
\end{array}$ & $\begin{array}{ll}8 & (4.8) \\
2 & (11.3) \\
3 & (8.5) \\
7 & (9.5) \\
\end{array}$ & $\begin{aligned} & 9(5.2) \\
& 5(8.0) \\
& 12(9.4) \\
& 7(10.5) \\
&\end{aligned}$ & $\begin{array}{l}+.37 \\
-.59 \\
+.09 \\
-.45 \\
\end{array}$ & 23.781 & 3 & $.000 *$ \\
\hline $\begin{array}{c}\text { Conduct Risk Assessment } \\
1 \\
2 \\
3 \\
4 \\
\end{array}$ & $\begin{array}{cl}1 & (6.3) \\
21 & (9.7) \\
3 & (11.3) \\
15 & (12.7) \\
\end{array}$ & $\begin{array}{ll}1 & (1.4) \\
1 & (2.2) \\
3 & (2.6) \\
4 & (2.8) \\
\end{array}$ & $\begin{array}{cc}17 & (11.2) \\
7 & (17.2) \\
28 & (20.1) \\
19 & (22.5) \\
\end{array}$ & $\begin{array}{l}+.84 \\
-.48 \\
+.74 \\
+.11 \\
\end{array}$ & 34.947 & 3 & $.000 *$ \\
\hline $\begin{array}{c}\text { Have Back-up Systems to } \\
\text { Communicate w/Employees } \\
1 \\
2 \\
3 \\
4 \\
\end{array}$ & $\begin{array}{cc}3 & (11.6) \\
27 & (17.6) \\
14 & (20.7) \\
29 & (23.1) \\
\end{array}$ & $\begin{array}{ll}5 & (2.2) \\
1 & (3.4) \\
2 & (4.0) \\
6 & (4.4) \\
\end{array}$ & $\begin{array}{rc}11 & (5.2) \\
1 & (8.0) \\
18 & (9.4) \\
3 & (10.5)\end{array}$ & $\begin{array}{l}+.42 \\
-.90 \\
+.12 \\
-.68\end{array}$ & 40.514 & 3 & $.000^{*}$ \\
\hline $\begin{array}{l}\text { Have Infrastructure in Place to } \\
\text { Resume Operations } \\
1 \\
2 \\
3 \\
4 \\
\end{array}$ & $\begin{aligned} & 1(5.9) \\
& 18(8.9) \\
& 5(10.5) \\
& 13(11.7) \\
&\end{aligned}$ & $\begin{array}{ll}0 & (1.6) \\
1 & (2.4) \\
2 & (2.8) \\
7 & (3.2) \\
\end{array}$ & $\begin{array}{ll}18 & (11.6) \\
10 & (17.6) \\
27 & (20.7) \\
18 & (23.1) \\
\end{array}$ & $\begin{array}{l}+.89 \\
+.28 \\
+.65 \\
+.13 \\
\end{array}$ & 25.946 & 3 & $.000 *$ \\
\hline $\begin{array}{l}\text { Coordinate with Public Agencies } \\
\text { to Assist Affected Employees } \\
1 \\
2 \\
3 \\
4 \\
\end{array}$ & $\begin{aligned} & 0(8.7) \\
& 22(13.3) \\
& 6(15.6) \\
& 27(17.4) \\
&\end{aligned}$ & $\begin{array}{ll}4 & (2.5) \\
2 & (3.9) \\
7 & (4.5) \\
3 & (5.1) \\
\end{array}$ & $\begin{array}{rr}15 & (7.8) \\
5 & (11.8) \\
21 & (13.9) \\
8 & (15.5) \\
\end{array}$ & $\begin{array}{l}+.79 \\
-.59 \\
+.44 \\
-.51 \\
\end{array}$ & 43.580 & 3 & $.000^{*}$ \\
\hline $\begin{array}{l}\text { Attend to Psych., Social \& } \\
\text { Financial Issues of } \\
\text { Employees/Families } \\
1 \\
2 \\
3 \\
4 \\
\end{array}$ & $\begin{array}{cc}4 & (13.0) \\
28 & (19.8) \\
15 & (23.2) \\
35 & (26.0) \\
\end{array}$ & $\begin{array}{lc}9 & (2.1) \\
0 & (3.1) \\
2 & (3.7) \\
2 & (4.1) \\
\end{array}$ & $\begin{array}{cc}6 & (4.0) \\
1 & (6.0) \\
17 & (7.1) \\
1 & (7.9) \\
\end{array}$ & $\begin{array}{l}+.11 \\
-.93 \\
+.06 \\
-.89 \\
\end{array}$ & 46.388 & 3 & $.000 *$ \\
\hline $\begin{array}{lll}\text { Note: } & \mathrm{a}- & 1=19(0-5 \text { years }) ; 2 \\
& \mathrm{~b}- & \text { Kruskal-Wallis Inde } \\
& \mathrm{c}- & \text { ob }=\text { observed; ex }= \\
& \mathrm{d}- & -1=\text { ineffective; } 0=1 \\
& * \text { significance at } .05\end{array}$ & $\begin{array}{l}9(6-10 \text { year } \\
\text { dent Samples } \\
\text { oected } \\
\text { pinion; }+1=\end{array}$ & $\begin{array}{l}34(11-15 \\
\text { tical Meas } \\
\text { ive }\end{array}$ & $; 4=38$ & & & & \\
\hline
\end{tabular}

A similar finding was derived in regards to perceptions related to operational tasks such as conducting a risk assessment for all facilities and having an infrastructure in place to resume operations. Again, those with less than 5 years of service were generally more positive in regards to these two observations $(\mathrm{m}=+.84, \mathrm{~m}=+.89)$ than those with greater work experience with an organization. Moreover, only for having an infrastructure in place were managers in agreement that their organization had planned to initiate practices to resume operations quickly after a natural disaster strikes $(\mathrm{m}=+.89,+.28,+.65,+.13$ respectively) (Table 5).

\section{DISCUSSION AND CONCLUSIONS}

The findings of this study suggest that there appears to be some disparity among managers in their perceptions to the degree of the effectiveness of their CEO in leading organizational natural disaster preparedness. In terms of organizational preparedness, there appears to be agreement among the managers that their leadership has 
been effective in putting into effect practices that support being knowledgeable of current risks and having an backup infrastructure in place to resume operations quickly once a natural disaster hits. However, there appears to be general disagreement as to how prepared their organizations are in supporting the individual needs of employees and their families. In regards to having practices in place to provide medical assistance and other aid for addressing the needs of employees, there is noticeable disagreement. Similarly, there was overall disagreement that their organizations had a capacity to communicate with workers and their families once a natural disaster strikes. Therefore, there appears to be a mixed perception (or a lack of clarity) among managers as to the effectiveness of their leadership in actually putting practices in place to address the possibility of a natural disaster.

Ironically, although the CEO is perceived as being active in compiling current information on an organization's natural disaster risks, he or she is perceived as not providing a similar degree of attention to the individual needs of employees via practices that provide personal assistance as a result of a direct strike of a natural disaster. In terms of location of the manufacturing facility, whether coastal or inland, there were no significant differences among the perceptions of their leadership. In regards to size of the company, those managers in larger organizations generally agreed that practices have been put into place to cope with a natural disaster whereas those in small- to mid-size organizations generally disagreed. Therefore, the leadership is smaller companies appear to be less attentive to putting into place practices that address the effects of a natural disaster. Finally, those relatively new to a company were more positive as to their CEO's effectiveness in meeting their personal and family needs.

Moreover, employee education, length of service, and size of organization were significant factors in the perceptions of managers of their CEO effectiveness. However, location of the actual manufacturing facility where the manager was employed was not a factor. Therefore the null hypothesis of the study that the perceptions of those in mid-management positions in the manufacturing sector of the effectiveness of their CEO in leading in organizational preparedness for synergizing pre-event planning practices to address needs of employees and their families will not vary by size of organization, length of employment, and education level is rejected. Only for the variable relating to the region of the country where the manager is located was the null hypothesis accepted.

Therefore, it may be concluded that in spite of a number of recent natural disasters within the borders of the United States, organizations appear to presently have a mixed record of pre-event planning. It appears that managers are generally more impressed with their CEO's attending to infrastructure and operational issues rather than attending to the personal needs of their employees and families whether they be medical, psychological or financial. Also, those managers in small organizations perceive themselves as being more vulnerable than others. In addition, those managers with greater education and length of service appear to be more critical of their CEO than others. In this regard, it may be concluded that there is some notable doubt as to the degree of organizational preparedness in its totality. The doubt appears to directly relate to the micro-needs of employees rather than to the overall systematic macro-needs of the organization.

\section{AUTHOR INFORMATION}

James Morrison (contact author) is a professor of organizational leadership in the School of Public Policy and Administration in the College of Arts and Sciences at the University of Delaware in Newark, DE. His area of research is assessing CEO effectiveness in natural disaster preparedness and executive innovation. He has published over 75 articles in professional journals and has presented over 90 papers at international conferences. He has also been the recipient of 7 outstanding college teaching awards over the past three decades. E-mail: jilm@udel.edu (Corresponding author)

Titi Oladunjoye is a professor of educational leadership at Albany State University in Albany, GA. His area of research is analyzing and designing strategies to enhance the integration of computer technology within educational institutions. He has been a Fulbright Scholar at the University of Technology in Jamaica as well as the recipient of several outstanding teaching and service awards over the past two decades. He has published extensively in professional journals as well as authored 6 books. He has presented over 50 papers at conferences around the world. E-mail: ganiyu.oladunjoye@asurams.edu 


\section{REFERENCES}

1. $\quad$ American Business Data Base (2012). 700 Larkspur Landing Circle, Larkspur, CA 94939.

2. Achenback, J. (2012). Seismic hazards: Japan earthquake and other tectonic surprises challenge scientific assumptions. Washington Post, March 9, 2012.

3. Bankoff, G. (2004). Time is of the essence. Disasters, vulnerability and history. International Journal of Mass Emergencies and Disasters, 22, No. 3, 23-42.

4. Bloom, J. (2001, November 30). Crisis management top of US CEOs agendas. PR Week (UK), 6.

5. Burnett, J. J. (1998, Winter). A strategic approach to managing crises. Public Relations Journal, 475 488.

6. Carney, A., \& Jorden, A. (1993, August). Prepare for business-related crises. Public Relations Journal, 34 -35 .

7. Coombs, T. W. (1999). Ongoing crisis communication. Thousand Oaks: SAGE Publications.

8. Drabek, Thomas (2001) .Disaster warning and evacuation responses by private business employees. Disasters, 25, (1), 76-94.

9. Jackson, S., \& Dutton, J. E. (1988). Discerning threats and opportunities. Administrative Science Quarterly, 33, 370-387.

10. Godschalk, D.R. (1991). Disaster mitigation and hazard management. E.D. Thomas, G.J. Hoetmer (Eds.), Emergency Management: Principles and Practice for Local Government, International City Management Association, Washington, DC (1991), 131-160.

11. Hutchins, H. Annulis, H. Gaudet, C. (2008). Crisis planning: Survey results from Hurricane Katrina and implications for performance improvement professionals. http://onlinelibrary.wiley.com/doi/10.1002/piq.20002/abstract

12. Kunreuther, Howard and Useem, Michael (2010). Learning from catastrophes: Strategies of reaction and response. Wharton Publishing, University of Pennsylvania. http://www.visitmyphilippines.com/images/ads/aa7aeca3ce9ab73291f2337e6c4a072b.pdf

13. National Association of Manufacturers (2009). http://www.nam.org/Statistics-And-Data/Facts- AboutManufacturing/Landing.aspx

14. Pauchant,T. C. \& Mitroff, I. I. (1992). Transforming the crisis-prone organization: Preventing individual, organizational and environmental tragedies. San Francisco, CA: Jossey-Bass Publishers.

15. Runyan, Rodney (2006). Small business in the face of crisis: Identifying barriers to recovery from a natural disaster. Journal of Contingencies and Crisis Management, DOI: 10.1111/j.1468-5973.2006.00477.x, 14, (1), 12-26.

16. Schoenberg, Allan. (2005) Do crisis plans matter? A new perspective on leading during a crisis. Public Relations Quarterly, H. J. Ventures International, 1-6. http://www.webpages.uidaho.edu/css594/secure/lessons/05/schoenberg\%20crisis\%20plann\%20leadrshp.pdf

17. Shrivastava, P.,Mtroff, I. Miller, D., \& Miglani, A. (1988). Understanding industrial crises. Journal of Management Studies, 2,285-303.

18. Waugh Jr., W.L. (2000). Living with hazards, dealing with disasters: An Introduction to emergency management. Armonk, NY: M.E. Sharpe).

19. Waugh W. L. \& R.J. Hy (1990). Handbook of emergency management: programs and policies dealing with major hazards and disasters. New York, NY: Greenwood Press.

20. Wooten, Lynn and James, Erika (2008). Linking crisis management and leadership competencies: The role of human resource development. Advances in Developing Human Resources, 10, (3), 352-379. 